\title{
NöroPLAY Yönteminin İzleminde Kullanılan NöroPLAY Oyun Davranış Değerlendirme Ölçeği ve NöroPLAY Ebeveyn Oyun Davranış Değerlendirme Ölçeğinin Geliştirilmesi
}

\author{
NeuroPLAY Play Behavior Assesment Scale and NeuroPLAY Parent \\ Play Behavior Assesment Scale Used in the Monitoring of the \\ NeuroPLAY Method
}

\author{
Müdriye Yıldız Bıçakçı1 ${ }^{1}$, Barış Ekici², Şerife Sezen Aksu ${ }^{3}$, Feyza Kutlu Konuk ${ }^{4}$, \\ Elif Nur Gürkan ${ }^{5}$, Öykü Su Unay ${ }^{6}$
}

\section{Makale Geçmişi \\ Geliş : 15 Aralık 2020 \\ Düzeltme : 9 Mart 2021 \\ Kabul : 29 Nisan 2021}

\section{Makale Türü}

Arasturma Makalesi

\section{Article History}

Received : 15 December 2020

Revised : 9 March 2021

Accepted : 29 April 2021

Article Type

Research Article
Öz: Bu araştırmada NöroPLAY yönteminin izleminde NöroPLAY Oyun Davranışı Değerlendirme Ölçeği ve NöroPLAY Ebeveyn Oyun Davranışı Değerlendirme Ölçeğinin geliştirilmesi amaçlanmıştır. Çalışma grubu 18-42 ay aralığında olan 91 çocuktan oluşmaktadır. Ölçeklerin yap geçerliliklerini belirleyebilmek amacıyla açımlayıcı faktör analizi yöntemi kullanılmıştır. Maddelerin bulundukları yapıya hizmet etme derecelerinin incelenmesi için düzeltilmiş madde -toplam korelasyonu değerlendirilmiştir. Ölçek puanlarının güvenirliğinin değerlendirilmesinde Cronbach alfa ve McDonald omega güvenirlik katsayıları kullanılmışır. Ölçeklerin yapısı ile ilgili kanıtlar elde edildikten sonra hatırlanma etkisini de ortadan kaldırmak amacıyla altı ay sonra aynı örneklemden tekrar veri toplanarak yapının doğrulanması amacıyla doğrulayıcı faktör analizi gerçekleştirilmiştir. Doğrulayıcı faktör analizi gerçekleştirilirken veri çoklu normal dağılım göstermediği için kestirim yöntemi olarak güçlü maksimum olabilirlik (robust maximum likelihood) yöntemi kullanılmıştır. Doğrulayıcı faktör analizi sonucunda elde edilen uyum indeksi değerleri, faktör yük değerleri ve hata varyansları incelenerek model veri uyumu değerlendirilmiştir. Öçeklerden elde edilen ölçümlerin geçerli ve güvenilir olduğu ortaya konulmuștur. Anahtar Kelimeler: Otizm Spektrum Bozukluğu Olan Çocuk, Otizm, Oyun, Ebeveyn Oyun Davranıșları.

Abstract: This study aimed to develop the NeuroPLAY Play Behavior Assesment Scale and NeuroPLAY Parent Play Behavior Assesment Scale in the follow-up of the NeuroPLAY method. The study group consists of 91 children aged 18-42 months. Exploratory factor analysis method was used in order to determine the construct validity of scales. The corrected item-total correlation was evaluated to examine the degree to which the items serve the structure they are in. Cronbach alpha and McDonald omega reliability coefficients were used to evaluate the reliability. After obtaining evidence about the structure of the scale, confirmatory factor analysis was performed to verify the structure by collecting data again from the same sample six months later in order to eliminate the recall effect. While performing the confirmatory factor analysis, the robust maximum likelihood method was used as the estimation method because the data did not show multiple normal distribution. Model data fit was evaluated by examining the fit index values, factor load values and error variances obtained as a result of the confirmatory factor analysis. The scales are valid and reliable.

Keywords: Child with Autism Spectrum Disorder, Autism, Play, Parental Play Behavior. 


\section{SUMMARY}

\section{Introduction}

Play provides physical, motor and cognitive support (Hamm, 2005; Yamaner, 2001). (Aldred, 2018; Bradshaw, 2017; Bussanich, 2017; Dammann, 2017; Green, 2010; Kasari, 2010; Parsons, 2017; Pickles, 2016; Stadnick, 2015).

As is known, autism spectrum disorder; It is a neurodevelopmental disorder that occurs in the first years of life, with various changes, communication, social relationships, and simple / repetitive attention and behavior (Emmons \& Anderson, 2005). Improvement in parents' play behaviors (Diken \& Mahoney 2013; Ginn, 2017; Liao et al.2014) in the reduction of autism risk (Green et al.2015) and autism symptoms (Rahman et al.2016; Green et al.2017) It is seen that it creates effects. Based on these thoughts, the NeuroPLAY Method is structured as an early intervention program that can be shaped according to the needs of it and the family (Ekici, Dursun, Gürkan, Kutlu Konuk, \& Yıldız Bıçakçı; 2017). This early intervention program is an intensified miscarriage and early intervention program for children with autism symptoms between 12-42 months and their parents (Ekici, 2018). Research on strengthening the play behaviors of children and parents In order to ask this question, it is necessary to carry out the reliability studies of the analysis tools based on the philosophy of this method in order to investigate and monitor this method, and it is aimed to development NeuroPLAY Play Behavior Assesment Scale and NeuroPLAY Parent Play Behavior Assesment Scale.

\section{Method}

The research was designed as a scale development study for the development of the NeuroPLAY Play Behavior Assesment Scale and NeuroPLAY Parent Play Behavior Assesment Scale the follow-up of the NeuroPLAY method (Tay \& Jebb, 2017). The ages of the children included in this study range between 1842 months. 10 of the children are girls and 81 of them are boys. Since the aim of this study was to develop the NeuroPLAY Play Behavior Assesment Scale and NeuroPLAY Parent Play Behavior Assesment Scale the follow-up of the NeuroPLAY method and to reveal its structure, exploratory factor analysis was used primarily to reveal the structure of the scales. In addition, the corrected item-total correlation was evaluated to examine the degree to which the items serve the structure they are in. Cronbach alpha and McDonald omega reliability coefficients were used to evaluate the reliability of the scale scores.

\section{Results}

The Explanatory Analysis of NeuroPLAY Play Behavior Assesment Scale has 22 items and a fourdimensional structure. In the four-dimensional structure named "Play Participation Behaviors", the second factor "Repetitive and Continuing Behaviors", "Imitation and Diversity" and the fourth factor "Use of Voice and Words", the first factor was "Repetitive and Continuing Behaviors" by examining the items under the 
Factors. The variance explained by the first factor was $38.64 \% ; 14.27 \%$ of the variance explained by the second factor; The factor explained in the environment where the variance explained by the third is $7.33 \%$ and the variance of the fourth is $5.62 \%$. Evaluation of the four-dimensional structure of Impaired Play Assesment Scale, which accounts for $68.86 \%$ of the total variance explained by the four-dimensional structure. For NeuroPLAY Play Behavior Assesment Scale, it is seen that the factor load values of the first factor are between 0.649 and 0.923 , the factor load values of the second factor are between 0.539 and 0.847 , the load values of the third factor are between 0.641 and 0.821 , and the load values of the $\mathrm{d}$ factors are between 0.594 and 0.808 .

It was determined that the NeuroPLAY Parent Play Behavior Assesment Scale obtained as a result of the exploratory factor analysis has 25 items and a five-dimensional structure. In the determined fourdimensional structure, the items under the Factors were examined and the first factor was "Interaction Skills in Play", the second factor was "Verbal Expression Use", the third factor was "Attention Supporting Approaches", the fourth factor was "Communication Skills in Play" and the fifth factor was "Non-Directive Approaches" named. The variance explained by the first factor is $30.07 \% ; 14.25 \%$ of the variance explained by the second factor; The variance explained by the third factor was $11.41 \%$, the variance explained by the fourth factor was $5.51 \%$, and the variance explained by the fifth factor was $4.53 \%$. It is $65.78 \%$ of the total variance explained by the five-dimensional structure of the NeuroPLAY Parent Play Behavior Assesment Scale. The fact that the total variance explained for the parent play form was $65.78 \%$, indicates that the appropriate number of dimensions for the scale was decided on this issue. Within the scope of the study, the factor load values of the first factor were between 0.736 and 0.832 , the factor load values of the second factor were between 0.540 and 0.802 , the factor load values of the third factor were between 0.531 and 0.884, the factor load values of the fourth factor were between 0.444 and 0.848 . and for the fifth factor, it is seen that the factor load values vary between 0.611 and 0.904. It was determined that Cronbach alpha values calculated for the dimensions for the NeuroPLAY Parent Play Behavior Assesment Scale varied between 0.602 and 0.888 and McDonald Omega values varied between 0.638 and 0.901 . It was determined that the calculated Cronbach alpha values for the dimensions for NeuroPLAY Play Behavior Assesment Scale ranged from 0.746 to 0.938 and the McDonald Omega values between 0.762 and 0.938 .

\section{Conclusion and Discussion}

NeuroPLAY Play Behavior Assesment Scale, the high value of variance explained is an indication that the related concept or structure is measured so well. The amount that explains two thirds (approximately 67\%) of the total variance related to the variables included in the analysis is considered important (Büyükzötürk, 2011). The fact that the total variance explained for the NeuroPLAY Play Behavior Assesment Scale is $68.86 \%$ indicates that the appropriate number of dimensions for the scale was decided in this regard. In addition, Kline (1994) means that item factor loading values of 0.60 and above are high, and 0.30-.59 is a moderately good criterion. Since the factor load value of each item under the dimensions is higher than 0.30 , it can be said that the items serve their purpose in the dimension they are in. Likewise, it can be said 
that the items serve their purpose in the dimension they are in, since the factor load value for each item under the dimensions in the NeuroPLAY Parent Play Behavior Assesment Scale is high. As a result, it was revealed that the measurements obtained from the Impaired Play Asesment Scale and the NeuroPLAY Parent Play Behavior Assesment Scale used in the NeuroPLAY method are valid and reliable. 


\section{GİRİŞ}

Oyun çocukların fiziksel, motor, bilişsel, dil ve sosyal duygusal gelişimlerine önemli destek sağlar (Hamm, 2005; Yamaner, 2001). Oyunun bu gücü -çeşitli gelissim özelliklere sahip tüm çocukların gelişim ve öğrenme süreçlerinde etkili olduğu ifade edilir. Otizm spektrum bozukluğu (OSB) olan çocukların güçlendirilmesinde de oyunun oldukça değerli olduğunu gösteren araştırma sonuçları vardır (Aldred, 2018; Bradshaw, 2017; Bussanich, 2017; Dammann, 2017; Green, 2010; Kasari, 2010; Parsons, 2017; Pickles, 2016; Stadnick, 2015).

Bilindiği gibi otizm spektrum bozukluğu; yaşamın ilk yıllarında ortaya çıkan, çocuğun gelişimini ve sosyal etkileşimini olumsuz yönde etkileyen, iletişim, sosyal etkileşim sorunları ve sınırlı/tekrarlı ilgi ve davranışlarla karakterize olan nörogelissimsel bir bozukluktur (Emmons ve Anderson, 2005; Filipek, 1999). Ruhsal Bozuklukların Tanısal ve Sayımsal Elkitabı-5/Diagnostic and Statistical Manual of Mental Disorders (DSM-V) tanı kriterlerine göre OSB çocuklar; sosyal duygusal yetersizlik, sözel olmayan iletişimde sınırlıklar, yaşa uygun ilişki kurma ve sürdürmede zorluklar, stereotipik veya tekrarlayan konuşma, motor hareketler veya nesne kullanımı veya kendine özgü sözel kalıpları kullanma, sözel-sözel olmayan ritüel hareketlere aşırı bağlllık veya değişime karşı aşırı direnç gösterme ve duyusal girdilere çok-az tepkiler veya çevrenin duyusal özelliklerine sıra dış1 tepkiler verme gibi özellikleri olan çocuklar olarak tanımlanmaktadır. OSB olan çocukların bu özelliklerine bağlı olarak da oyun becerilerinde güçlükler görülmektedir. Bu nedenle OSB olan çocukların oyun üzerinden desteklenmesi için ebeveyn desteğine ihtiyaç duyulmakta, ebeveyn ve ev merkezli temelli erken müdahale programları uygulanmaktadır (Case-Smith \& Arbesman, 2008; Schultz, 2011; Tonge, 2014; Ginn et al. , 2017; Green et al. 2017; Juffer \& Bakermans-Kranenbur, 2018). Ebeveyn temelli erken müdahale programlarının otizm riskinin (Green et al. 2015) ve otizm semptomlarının azalmasında (Rahman et al. 2016; Green et al. 2017), çocukların sosyal etkileşim (Casenhiser, 2013; Kasari, 2014; Rahman et al. 2016; Schertz, 2013), ortak dikkat (Kasari, 2010; Kasari, 2014; Shire et al. 2017), sosyal tepki (Ingersol \& Wainer 2013), taklit ve sembolik oyun gibi alanlarda kazanımlar elde etmesinde (Charman et al. 2003; Kasari, 2014), ebeveyn çocuk etkileşiminin artmasında (Bussanich, 2017; Green et al. 2010; Siller, 2013) ve ebeveynlerin oyun davranışlarında iyileşmeler sağlayarak (Diken \& Mahoney 2013; Ginn, 2017; Liao et al. 2014) farklı alanlarda olumlu etkiler yarattığ1 görülmektedir. OSB olan çocuklara yönelik oyun ve ebeveyn temelli müdahale programların etkileri göz önünde bulundurulduğunda (Ginn et al. , 2017; Green et al. 2017; Frost, Russell \& Ingersoll, 2021) hem ebeveyn etkileşimi hem oyunu hem de ev merkezli olan programların daha etkili olacağı düşünülmektedir. 
Bu gerekçelerden yola çıkarak oluşturulan NöroPLAY Yöntemi her çocuğun ve ailenin ihtiyacına göre şekillenebilen bir erken müdahale programı olarak yapılandırılmıştır (Ekici, Dursun, Gürkan, Kutlu Konuk \& Yıldız Bıçakçı; 2017). Bu erken müdahale programı, 12-42 ay arasında otizm semptomları olan çocuk ve ebeveynlerine yönelik geliştirilmiş yoğunlaştırılmış düşük maliyetli ve ev -temelli bir erken müdahale programıdır (Ekici, 2018). Bu program, OSB olan çocukların gelişim, duyu, öğrenme özellikleri, oyun davranışları ve ebeveynlerin özellikleri ve oyun davranışları temel alınarak; ebeveyn-çocuk etkileşimini arttırma yoluyla çocukların otizm şiddetlerinin azalmasını, bunun yanı sıra ise hem çocukların hem de ebeveynlerin sosyal oyun davranışlarını güçlendirmeyi hedefleyen yöntemdir. Yöntem, gelişim ve öğrenme kuramları ile oyunun gücünün birleşmesiyle oluşturulmuş olup, çocuk ve en yakın çevresi aileyi güçlendirmeyi amaçlamaktadır (Ekici, 2018; Ekici, 2019; Ekici, 2020). Çocukların ve ebeveynlerin oyun davranışlanını güçlendirme amac1 doğrultusunda uygulanan programın etkililiği hem çocuk hem de ebeveynlerin oyun davranışları üzerinden izlenmesini içermektedir. Bilindiği gibi çocuğa sunulan oyun süreci gözlenerek, çocuğun ve ebeveynlerin davranışlarını hakkında bilgi edinilmektedir (Aksoy ve DereÇiftçi, 2014). Bu nedenle bu yöntemin değerlendirilmesi ve izlenmesi için yöntemin felsefesine dayanan değerlendirme araçlarına ait geçerlik güvenirlik çalışmalarının yapılması önemli olup, bu çalışmada NöroPLAY Oyun Davranışı Değerlendirme Ölçeği ve NöroPLAY Ebeveyn Oyun Davranış1 Değerlendirme Ölçeğinin geliştirilmesi amaçlanmıştır.

\section{YÖNTEM}

\section{Araştırmanın Modeli}

Araştırma NöroPLAY yönteminin izleminde NöroPLAY Oyun Davranış Değerlendirme Ölçeği ve Ebeveyn Oyun Davranış Değerlendirme Ölçeğinin geliştirilmesine yönelik olarak bir ölçek geliştirme -çalışmasıdır. Ölçek geliştirme, ilgilenilen bir niteliği değerlendirmek ve güvenilir ve geçerli bir ölçüsünü oluşturma sürecidir. Gözlemlenebilir özelliklerin (yükseklik, hız vb) aksine gözlemlenemeyen yapılar (öz değerlendirme gibi) genellikle çok soyuttur ve hangi öğelerin onları yeterince temsil ettiği belirlemek zorlu bir görevdir. Ölçeklere konu olan yapılar karmaşıktır ve tek bir kavram olmaktan ziyade farklı bileşenlerden oluşabilir (Tay ve Jebb, 2017).

\section{Çalışma Grubu}

Çalışma grubuna dahil edilen çocuklar Çocukluk Otizmi Derecelendirme Formu (Childhood Autism Rating Scale-CARS) kullanılarak tespit edilmiş ve bu doğrultuda 91 çocuk ve onların ebeveynleri çalışma grubuna dahil edilmiştir. Çocukluk Otizmi Derecelendirme Formu (CARS) 
Schopler, Reichler, DeVellis ve Daly (1980) tarafından geliştirilmiş, Hegüner ve Özbaran (2010) tarafından Türkçe'ye çevrilmiştir. CARS 15 maddeden oluşmaktadır ve tek boyutlu yapıya sahiptir. CARS Türkçe versiyonu için İncekkaş Gassaloğlu, Baykara, Avcil ve Demiral (2016) tarafindan geçerlik ve güvenirlik çalışması gerçekleştirilmiştir. Bu çalışmada yapılan açımlayıcı faktör analizi yapılan ROC analizi sonucunda kesme puanı 29,5 olarak belirlenmiştir. Bu araştırmaya dahil edilen çocukların yaşları 18-42 ay arasında değişmektedir. Çocukların 10’u kız ve 81'i erkektir. Ölçek geliştirme çalışmalarında örneklem büyüklügüumü konusunda alan yazında farklı görüşler bulunmaktadır. Örneklem büyüklüğü ne kadar fazla ise o kadar iyi olacağı görüşüyle birlikte, net bir faktör yapısının 100 kişilik bir örneklemde genellikle güvenilir sonuçlar elde edilerek analiz edilebileceğidir (Kline, 1994, s.73). Bir diğer görüşte ise faktör analizi için örneklem büyüklüğünün madde sayısının en az 10 katı olması gerektiği -belirtilmiştir (Crocker ve Algina, 1986, s.296). Çokluk, Şekercioğlu ve Büyüköztürk (2010, s.206) ise faktör analizinin yapılabilmesi için örneklem büyüklüğünün madde sayısının en az iki katı kadar olması gerektiğini belirtmiştir. Çalışma kapsamında çalışan grubun dezavantajlı olan bir grup olması da göz önüne alındığında, ölçekte yer alan madde sayısının yaklaşık üç katı örnekleme ulaşılmış ve bu değerin yeterli örneklem büyüklüğü olduğu kabul edilmiştir. Ayrıca örneklem büyüklüğünün faktör oluşturmaya uygunluğunun değerlendirilmesi için KMO (Kaiser-MEyer-Olkin) ve Bartlett istatistiği değerleri incelenmiştir. KMO değerinin 0,60'dan daha büyük olması ve Bartlett testi sonuçlanının istatistiksel olarak anlamlı farklılık göstermesi verinin faktör analizi için uygun olduğu anlamına gelmektedir (Tabachnick ve Fidel, 2012, ss.619-620).

Çalışma İstinye Üniversite etik kurul izni alındıktan sonra İstanbul ilinde özel çocuk nöroloji kliniğine çocuğu OSB riski olduğunu düşüncesiyle başvuruda bulunmuş olan ebeveynlerden onam formu alınarak sürdürülmüştür. Çalışmaya dahil edilme kriteri olarak çocukların otizm belirtileri dışında farklı bir engel durumunun olmaması, NöroPLAY yönteminin uygulanmasına onay vermesi ve çalışmaya gönüllü katılım kriterleri göz önünde bulndurulmuştur. Bu kriterlere uyan ebeveynlerden hem kendileri hem de çocukları için onam formu imzalı olarak alınmıştır.

\section{Veri Toplama Araçları}

Araştırma NöroPLAY yönteminin izleminde NöroPLAY Oyun Davranış Değerlendirme Ölçeği ve NöroPLAY Ebeveyn Oyun Davranış Değerlendirme Ölçeğinin geliştirilmesini amaçlamaktadır. $\mathrm{Bu}$ amaçla araştırmacılar tarafindan geliştirilen ölçek formları veri toplama araçları olarak kullanılmıştır. NöroPLAY yöntemi, Ekici, Aksu, Yıldız Bıçakçı, Dursun, Kutlu Konuk ve Gürkan (2017) tarafindan geliştirilen, 12-42 aylık OSB olan çocuklar için ev temelli aile aracıll erken 
müdahale aracıdır. Ebeveyn-çocuk etkileşimlerine dayalı yoğun bir oyun temelli erken müdahale sürecidir. NöroPLAY erken müdahale yöntemi, çocuğun doğal ev ortamını dikkate alır. Ev ortamında şekillenen sosyal oyun oynama yoluyla çocuklarda tespit edilen sosyal rahatsılikların iyileştirilmesini amaçlamaktadır. Ev ortamına odaklanmanın temel nedeni, çocukların zamanlarının çoğunu evde yaşaması ve geçirmesidir. NöroPLAY erken müdahale programı, ev ortamında desteğin genelleştirilmesi ve sürekliliği felsefesine dayanmaktadır (Ekici, 2018). Bu program evde ebeveynler ve bakıcılar tarafından uygulandığı için ebeveynler ve birincil bakıcılar desteklenmektedir (Ekici, 2019). Bu programın diğer özellikleri arasında süreçleri çocuğa göre şekillendirme, yapılandırılmamış oyunlar, ortak ilgiye odaklanma ve disiplinler arası yaklaşım bulunmaktadır (Aksu, Ekici, Dursun, Gürkan, Kutlu Konuk ve Yıldız Bıçakçı 2017; Ekici, 2018).

\section{Verilerin Analizi}

Araştırma kapsamında geliştirme aşaması sunulan NöroPLAY Oyun Davranış Değerlendirme Ölçeği ve NöroPLAY Ebeveyn Oyun Davranış Değerlendirme Ölçeklerinin yap1 geçerliliklerini belirleyebilmek amacıyla faktör analizi yöntemi kullanılmıştır. Faktör analizi, aynı yapıyı ya da niteliği ölçen değişkenleri bir araya toplayarak ölçmeyi az sayıda faktör ile açılamayan bir istatistiksel tekniktir. Açımlayıcı (keşfedici) ve doğrulayıcı olmak üzere iki tür faktör analizi yaklaşımı vardır (Büyüköztürk, 2011, s.123). Ölçek geliştirme ve uyarlama çalışmalarının yap1 geçerliğine ilişkin kanıt elde etmek için en sık tercih edilen yöntemlerden biri faktör analizidir. Faktör analizi ölçme aracının geçerliğine ilişkin tek bir kanıt vermek yerine, faktör yapısını ortaya çıkarır ya da daha önceden geliştirilen faktör yapısını doğrulamaktadır. Yapı geçerliğine ilişkin deneysel kanıtların ortaya konulmasında tek bir yöntem yoktur ve yapı geçerliğinin ortaya konulması yaratıcı bir süreç içermektedir. Daha önceden yapısına ilişkin geçerlik-güvenirlik kanıtı bulunmayan ve yeni geliştirilen ölçme araçlarının yapısını belirlemek için açımlayıcı faktör analizinin kullanımı öncelikli olarak önerilirken; geçerlik ve güvenirlik kanıtlarına sahip özgün araçların uyarlanması çalışmalarında modelin geçerliğinin incelenmesi ilk olarak doğrulayıcı faktör analizi ile yapılabilir (Büyüköztürk, Çokluk ve Şekercioğlu, 2010, s.177-178). Bu çalışmanın amac1, NöroPLAY yönteminin izleminde NöroPLAY Oyun Davranış Değerlendirme Ölçeği ve NöroPLAY Ebeveyn Oyun Davranış Değerlendirme Ölçeğinin geliştirilmesi ve yapısının ortaya konulması olduğundan dolayı çalışmada öncelikli olarak ölçeklere ait yapıyı ortaya çıkarmak amacıyla açımlayıcı faktör analizi kullanılmıştır. Ayrıca maddelerin bulundukları yapıya hizmet etme derecelerinin incelenmesi için düzeltilmiş madde -toplam korelasyonu değerlendirilmiştir. Ölçek puanlarının güvenirliğinin değerlendirilmesinde Cronbach alfa ve McDonald omega güvenirlik katsayıları kullanılmıştır. Ölçeğin yapısı ile ilgili kanıtlar elde edildikten sonra hatırlanma etkisini de ortadan kaldırmak 
amacıyla altı ay sonra aynı örneklemden tekrar veri toplanarak yapının doğrulanması amacıyla doğrulayıcı faktör analizi gerçekleştirilmiştir. Doğrulayıcı faktör analizi gerçekleştirilirken veri çoklu normal dağılım göstermediği için kestirim yöntemi olarak güçlü maksimum olabilirlik (robust maximum likelihood) yöntemi kullanılmıştır. Tek değişkenli normallik için basıklık ve çarpıklık değerleri incelenirken çok değişkenli normallik varsayımı için Mardia test incelenmiştir. Mardia test sonucuna göre değişkenlerin çoklu normal dağılım göstermediği tespit edilmiştir. Doğrulayıcı faktör analizi sonucunda elde edilen uyum indeksi değerleri, faktör yük değerleri ve hata varyansları incelenerek model veri uyumu değerlendirilmiştir. Uyum indeksleri değerleri için önerilen uyum indeksi değerlerinin kabul edilebilir uyum düzeyi aralıkları (Schermelleh-Engel, Moosbrugger, ve Müller, 2003; Awang, 2015) Tablo 1'de sunulmuştur.

Tablo 1. Doğrulayıcı faktör analizi uyum indeksi değerleri önerilen kabul edilebilir uyum indeksi aralıkları

\begin{tabular}{cc}
\hline Uyum İndeksi & Kabul Edilebilir düzey \\
\hline Ki-kare & $\mathrm{p}>0,05$ \\
Ki-kare/sd & $<3.0$ \\
RMSEA & $<0,08$ \\
GFI & $>0,90$ \\
CFI & $>0,90$ \\
NFI & $>0,90$ \\
\hline
\end{tabular}

\section{BULGULAR}

Araştırma kapsamında geliştirme aşaması sunulan NöroPLAY Oyun Davranış Değerlendirme Ölçeği ve NöroPLAY Ebeveyn Oyun Davranış Değerlendirme Ölçeğinden elde edilen ölçümlerin yapı geçerlilikleri ve güvenirlikleri ile ilgili elde edilen bulgular bu bölümde sunulmuştur.

\section{NöroPLAY Oyun Davranış Değerlendirme Ölçeği}

NöroPlay yönteminin izlenmesinde kullanılan NöroPLAY Oyun Davranış Değerlendirme Ölçeği 35 maddeden oluşmaktadır. Ölçek maddeleri yazılırken ilgili alan taraması (Charman et al. 2003; Kasari, 2010; Casenhiser, 2013; Diken \& Mahoney 2013; Ingersol \& Wainer 2013; Kasari, 2014; Liao et al. 2014; Rahman et al. 2016; Ginn, 2017; Green et al. 2017; Shire et al. 2017) ve uzman görüşleri dikkate alınarak hazırlanmıştır. Maddeler otizm spektrumu tanısı olan çocukların oyun davranışlarını değerlendirmeye yönelik olarak yazılmıştır. NöroPLAY Oyun Davranış Değerlendirme Ölçeği çocuğun oyuna pasif katılımı, aktif oyun davranışı, oyun içindeki duyusal problemini belli eden davranışlar, oyuncakları amacına uygun kullanmaması, oyuncakları tekrarlı şekilde kullanması, tekrarlı oyun davranışları, oyundaki dikkat süreleri, taklit ve çocuğun oyundaki ses/sözcük kullanımı ile ilgili maddeleri içermektedir. 


\section{NöroPLAY Oyun Davranış Değerlendirme Ölçeği Ölçümlerine ait Yapı Geçerliği}

\section{Bulgular1}

NöroPLAY Oyun Davranış Değerlendirme Ölçeği ne yönelik yazılan maddelerin amacına hizmet etme durumunu ve belirttiği yapıyı incelemek amacıyla temel bileşenler analizine dayalı faktör analizi yapılmıştır. Faktör analizi yapılmadan önce örneklem büyüklüğünün yeterliliğini ve veri setinin faktörleşmeye uygunluğunu değerlendirmek için KMO (Kaiser-MEyer-Olkin) ve Bartlett istatistiği değerleri incelenmiştir. Faktör analizi yapılırken faktör yük değerlerinin 0,30 'dan yüksek olmasına ve binişik madde olmamasina dikkat edilmiştir. Faktör yük değeri 0,30'dan düşük olanlar ve binişik olan maddeler analiz dışında bırakılarak analizler tekrarlanmıştır. Bu bağlamda 13 madde (6-13-1516-17-19-22-23-24-28-30-31-32) analiz dışında bırakılmıştır. En son gerçekleştirilen faktör analizi için hesaplanan KMO değeri 0,843 ve Bartlett istatistiği değeri 1683,152 (sd =231, p<0,05) olarak belirlenmiştir. Buna göre, örneklem büyüklüğünün yeterli ve veri setinin faktörleşmeye uygun olduğu söylenebilir. Faktör analizi sonucunda elde edilen faktör yük değerleri ve açılanan varyans oranları Tablo 2'de sunulmuştur.

Tablo 2. NöroPLAY Oyun Davranış Değerlendirme Ölçeği faktör analizi sonucunda elde edilen öz değerler ve açıklanan varyans yüzdeleri

\begin{tabular}{cccc}
\hline & Öz Değer & Açılanan Varyans Oran1 & Toplam Açıklanan Varyans \\
\hline 1 & 8,502 & 38,643 & 38,643 \\
2 & 3,140 & 14,272 & 52,916 \\
3 & 1,613 & 7,333 & 60,249 \\
4 & 1,236 & 5,616 & 65,865 \\
5 &, 881 & 4,007 & \\
6 &, 834 & 3,792 & \\
7 &, 765 & 3,478 & \\
8 &, 712 & 3,235 & \\
9 &, 610 & 2,771 & \\
10 &, 563 & 2,560 & \\
11 &, 489 & 2,223 & \\
12 &, 443 & 2,015 & \\
13 &, 408 & 1,856 & \\
14 &, 334 & 1,517 & \\
15 &, 310 & 1,410 & \\
16 &, 268 & 1,217 & \\
17 &, 252 & 1,144 & \\
18 &, 180 &, 820 & \\
19 &, 146 &, 663 & \\
20 &, 136 &, 619 & \\
21 &, 106 &, 480 & \\
22 &, 072 & & \\
\hline
\end{tabular}




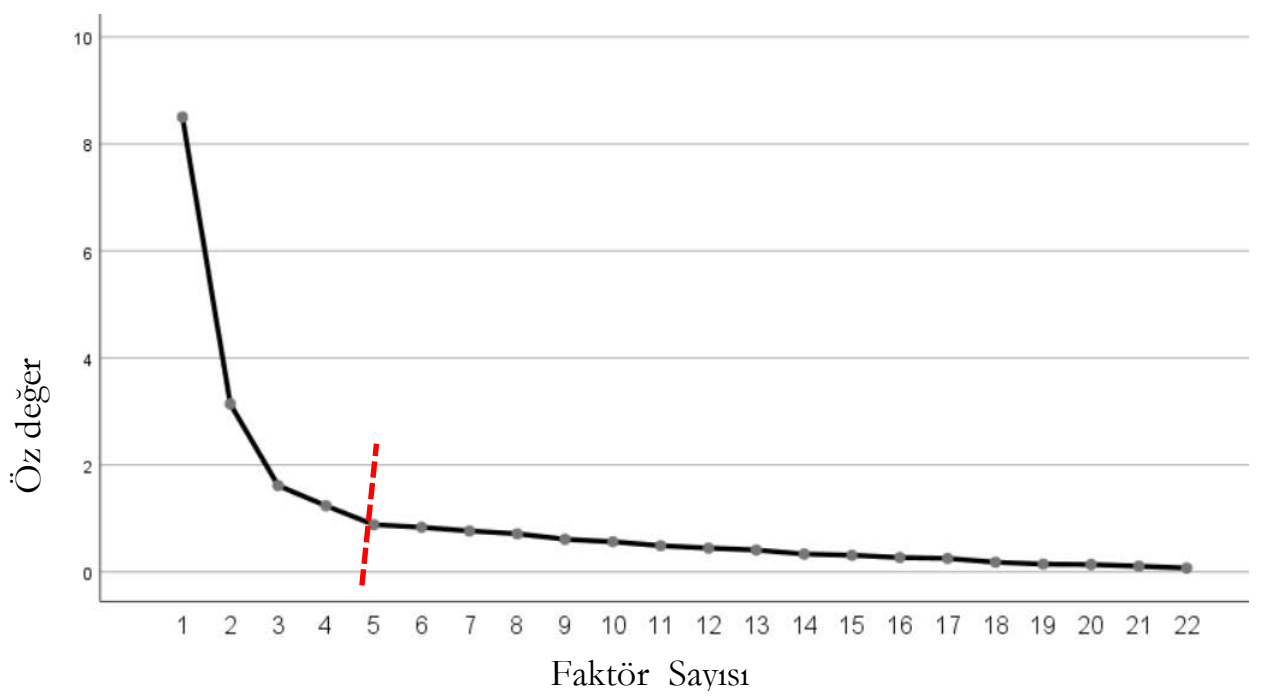

Şekil 1. NöroPLAY Oyun Davranış Değerlendirme Ölçeği yamaç-birikinti grafiği

Tablo 2 incelendiğinde öz değeri 1'in üzerinde olan dört faktör olduğu görülmektedir. Buna göre NöroPLAY Oyun Davranış Değerlendirme Ölçeği nin dört faktörden oluştuğu söylenebilir. Ayrıca Şekil 1'de verilen yamaç-birikinti grafiği (scree plot) incelendiğinde grafiğin düzleşmeye başladığ1 kısmın dördüncü boyuttan sonra olduğu görülmektedir. Buna göre, yamaç birikinti grafiğinin de dört boyutlu yapıyı desteklediği söylenebilir. NöroPLAY Oyun Davranış Değerlendirme Ölçeği açıklanan varyans oranı ise \% $\% 8,86$ olarak tespit edilmiştir. Diğer bir deyişle 22 madde dört boyutlu yapıdaki varyansın \%68,86’sını açıklamaktadır. NöroPLAY Oyun Davranış Değerlendirme Ölçeği nde kalan maddelerin faktörlere göre dağılımı ve faktör yük değerleri Tablo 3'de sunulmuştur.

Tablo 3. NöroPLAY Oyun Davranış Değerlendirme Ölçeği faktör yük değerleri

\begin{tabular}{|c|c|c|c|c|}
\hline & \multicolumn{4}{|c|}{ Faktör } \\
\hline & 1 & 2 & 3 & 4 \\
\hline 1.Akranlar1 ile aynı ortamda durmak istemez. & 904 & & & \\
\hline 2.Paralel oyun oynamaz. & 923 & & & \\
\hline $\begin{array}{l}\text { 3.İlgisini çeken oyuncak/oyun materyali kullanarak anne/babasıyla (birincil } \\
\text { bakım veren kişiye) iletişimi başlatmaz. }\end{array}$ & ,786 & & & \\
\hline $\begin{array}{l}\text { 4.Anne/babasiyla (birincil bakım veren kişiye) ilgisini çeken oyuncak/oyun } \\
\text { materyali kullanarak oyun kurmaya istekli davranmaz. }\end{array}$ & 891 & & & \\
\hline $\begin{array}{l}\text { 5.Anne/babası (birincil bakım veren kişi) yanında bir oyun kurduğunda oyuna } \\
\text { dahil olmaz hatta dönüp bakmaz/ilgilenmez. }\end{array}$ & ,836 & & & \\
\hline 7.Akranları yanında oyun oynadığında onlara dahil olmak istemez. & ,897 & & & \\
\hline 8.Tek başına oyuna meyillidir. & ,649 & & & \\
\hline $\begin{array}{l}\text { 9. Oyununa dahil olmaya çalışan anne/babası (birincil bakım veren kişi) veya } \\
\text { akranını reddeder. }\end{array}$ & ,774 & & & \\
\hline $\begin{array}{l}\text { 14.Açılabilir nesne/oyuncak/oyun materyallerinin kapaklarını / kapılarını sürekli } \\
\text { açıp kapar. Örneğin, dolap kapakları, oyuncak araba kapıları, odanın kapısı gibi. }\end{array}$ & & & & \\
\hline
\end{tabular}


20.Aynı nesne/oyuncak/oyun materyali türü ile 1srarla oynamak ister. Örneğin; kulplu oyuncaklar, üzerinde sayı olan oyuncaklar gibi.

, 776

, 847

,707

,699

, 699

34.Anlamlı görünen bir sembolik oyunu tekrarlı bir şekilde anlamsızca oynar.

Örneğin; sürekli çaydanlıktan bardağa su dolduruyormuş gibi yapar veya

dolabın içine tabağı koyar kapağı kapatır, sonra tekrar kapağı açar tabağı alır.

10. Oyun içerisinde davranış taklitleri yapmaz.

11.Oyun içerisinde sözel/sese dayalı taklitleri yapmaz.

12.Oyun içerisinde sözcükleri iletişim aracı olarak kullanmaz. $\quad, 714$

$\begin{array}{ll}35 . \text { Oyun çeşitliliği sağlayamaz. } & , 787\end{array}$

18.Nesne/oyuncak/oyun materyallerin renklerini, şekillerini, isimlerini vb. $\quad 819$

söyleyip birakır.

26. Kendi kendine mirıldanir. $\quad, 594$

$\begin{array}{lr}\text { 27.Kendi kendine şarkı söyler. } & , 708\end{array}$

29.Oyunda oynayan kişiden duyduğu bir sesi anlamsız şekilde sürekli tekrarlar. $\quad$ 808

Tablo 3 incelendiğinde faktör 1 için faktör yük değerleri 0,649 ile 0,923 arasında, faktör 2 için 0,539 ile 0,847 arasında, faktör 3 için 0,641 ile 0,821 arasında ve faktör 4 için 0,594 ile 0,808 arasında değiştiği görülmektedir. Her bir madde için faktör yük değeri 0,30’un yüksek olduğu için maddelerin bulundukları boyutta amacına hizmet ettikleri söylenebilir. Faktörler altında yer alan maddeler incelendiğinde birinci faktör "Oyun Katılım Davranışları”, ikinci faktör “Tekrarlı ve Devam Eden Davranışlar”, üçüncü faktör "Taklit ve Çeşitlilik” ve dördüncü faktör "Ses ve Sözcük Kullanımı” olarak isimlendirilmiştir.

NöroPLAY Oyun Davranış Değerlendirme Ölçeği 22 maddeden oluşan dört boyutlu bir yap1 göstermektedir. Elde edilen bu dört boyutlu yapının doğrulanması amaciyla hedef gruptan altı ay sonra toplanan veriler üzerinden doğrulayıcı faktör analizi yapılmıştır. Doğrulayıcı faktör analizi yapılırken uyum indeksi değerleri, faktör yük değerleri ve hata varyansları incelenerek model veri uyumu değerlendirilmiştir. Uyum indeksi değerleri, faktör yük değerleri (max-min) ve hata varyansı (max-min) değerleri Tablo 4'te sunulmuştur. Ayrıca analiz sonucunda elde edilen ölçme modeli Şekil 2'de sunulmuştur.

Tablo 4. NöroPLAY Oyun Davranış Değerlendirme Ölçeği Doğrulayıcı Faktör Analizi Sonuçları

\begin{tabular}{|c|c|c|c|c|c|c|c|c|c|}
\hline & & & & & & & & $\begin{array}{c}\text { Faktör Yük } \\
\text { Değerleri }\end{array}$ & $\begin{array}{c}\text { Hata } \\
\text { Varyanslar1 }\end{array}$ \\
\hline & $\chi^{2}$ & $\chi^{2} / \mathrm{sd}$ & $\mathrm{p}$ & CFI & GFI & NFI & RMSEA & $\max \quad \min$ & $\max \min$ \\
\hline Ölçek & 78,94 & 0,39 & 1,00 & 1,00 & 0,93 & 0,98 & 0,000 & 0,73 & $0,70 \quad 0,47$ \\
\hline Önerilen & & $\chi^{2} / \mathrm{sd} \leq 3$ & & $\geq 90$ & $\geq 90$ & $\geq 90$ & $\leq 0,080$ & $\geq 0,30$ & $\leq 0,90$ \\
\hline
\end{tabular}

Tablo 4 incelendiğinde $\chi 2 / s d$ değerinin 3’ten küçük olduğu görülmektedir ve buna göre modelin veriye çok iyi uyum gösterdiği söylenebilir. CFI değeri 1,00; GFI değeri 0,93 ve NFI değeri 0,98 
olarak tespit edilmiştir. Bu değerlerin 0,90'nın üzerinde olması modelin veriye çok iyi uyum gösterdiği anlamına gelmektedir. RMSEA indeksi açısından değerlendirildiğinde ise bu indeksin model için 0,000 olduğu saptanmıştır ve bu indekse göre modelin veriye çok iyi uyum gösterdiği söylenebilir. Uyum indeksleri genel olarak değerlendirildiğinde dört boyutlu modelin veriye uyum sağladığı görülmektedir. Ölçekteki tüm maddelerin faktör yük değerleri 0,30'dan yüksektir. Buna göre, tüm maddelerin amacına hizmet ettiği yorumu yapılabilir.

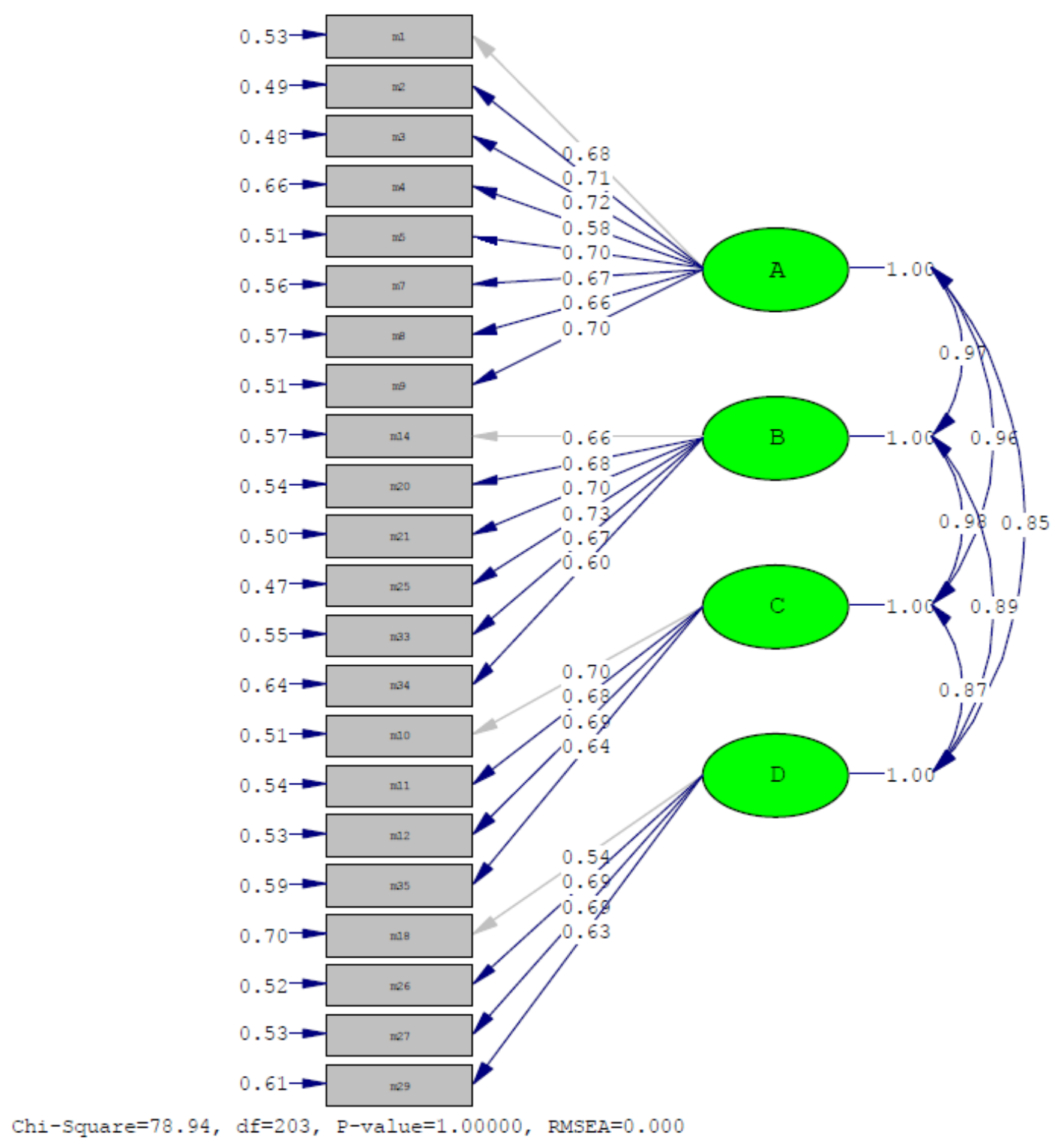

Şekil 2. NöroPLAY Oyun Davranış Değerlendirme Ölçme Modeli 


\section{NöroPLAY Oyun Davranış Değerlendirme Ölçeği ölçümlerine ait güvenirlik bulguları}

NöroPLAY Oyun Davranış Değerlendirme Ölçeğinin belirlenen faktörlerinde yer alan maddelerin madde ayırt ediciliğini incelemeye yönelik düzeltilmiş madde-toplam puanı korelasyonu ve faktörlerin güvenirliğinin belirlenmesine ilişkin Cronbach alfa değerleri ile McDonald Omega değerleri Tablo 5’te sunulmuştur.

Tablo 5. NöroPLAY Oyun Davranış Değerlendirme Ölçeği düzeltilmiş madde-toplam puanı korelasyonu, Cronbach alfa ile MacDonald Omega değerleri

\begin{tabular}{|c|c|c|c|c|}
\hline & $\begin{array}{l}\text { Madde } \\
\text { No }\end{array}$ & $\begin{array}{c}\text { Düzeltilmiş Madde -Toplam } \\
\text { Korelasyonu }\end{array}$ & $\begin{array}{c}\text { Cronbach } \\
\text { alfa }\end{array}$ & $\begin{array}{l}\text { McDonald } \\
\text { Omega }\end{array}$ \\
\hline \multirow{8}{*}{ Oyun Katılım Davranışları } & 1 & 0,699 & \multirow{8}{*}{0,938} & \multirow{8}{*}{0,938} \\
\hline & 2 & 0,779 & & \\
\hline & 3 & 0,798 & & \\
\hline & 4 & 0,835 & & \\
\hline & 5 & 0,774 & & \\
\hline & 7 & 0,823 & & \\
\hline & 8 & 0,735 & & \\
\hline & 9 & 0,792 & & \\
\hline \multirow{6}{*}{$\begin{array}{c}\text { Tekrarlı ve Devam Eden } \\
\text { Davranışlar }\end{array}$} & 14 & 0,542 & \multirow{6}{*}{0,829} & \multirow{6}{*}{0,834} \\
\hline & 20 & 0,484 & & \\
\hline & 21 & 0,614 & & \\
\hline & 25 & 0,662 & & \\
\hline & 33 & 0,722 & & \\
\hline & 34 & 0,585 & & \\
\hline \multirow{4}{*}{ Taklit ve Çeşitlilik } & 10 & 0,758 & \multirow{4}{*}{0,833} & \multirow{4}{*}{0,842} \\
\hline & 11 & 0,830 & & \\
\hline & 12 & 0,719 & & \\
\hline & 35 & 0,385 & & \\
\hline \multirow{4}{*}{ Ses ve Sözcük Kullanımı } & 18 & 0,479 & \multirow{4}{*}{0,746} & \multirow{4}{*}{0,762} \\
\hline & 26 & 0,590 & & \\
\hline & 27 & 0,549 & & \\
\hline & 29 & 0,615 & & \\
\hline
\end{tabular}

Tablo 5 incelendiğinde oyun katılım davranışları faktöründeki maddeler için düzeltilmiş maddetoplam puan korelasyonu değerinin 0,699 ile 0,835 arasında değiştiği görülmektedir. Bu değerler 0,30’un üzerinde olduğu için bu boyutta yer alan maddelerin amacina hizmet ettiği söylenebilir. Oyun katılım davranışları faktörü puanları için elde edilen Cronbach alfa değerinin 0,938 ve McDonald omega değerinin 0,938 olduğu belirlenmiş, bu değerler 0,70'den yüksek oldu için bu faktörden elde edilen ölçek puanlarının güvenilir olduğu söylenebilir. Tekrarlı ve devam eden davranışlar faktörü için için düzeltilmiş madde-toplam puan korelasyonu değerinin 0,484 ile 0,722 arasında değiştiği görülmektedir. Bu değerler 0,30’un üzerinde olduğu için bu boyutta yer alan maddelerin amacına hizmet ettiği söylenebilir. Tekrarlı ve devam eden davranışlar faktörü puanları için elde edilen Cronbach alfa değerinin 0,829 ve McDonald omega değerinin 0,834 olduğu 
belirlenmiş, bu değerler 0,70'den yüksek oldu için bu faktörden elde edilen ölçek puanlarının güvenilir olduğu söylenebilir. Taklit ve çeşitlilik faktörü için düzeltilmiş madde-toplam puan korelasyonu değerinin 0,385ile 0,830 arasında değiştiği görülmektedir. Bu değerler 0,30’un üzerinde olduğu için bu boyutta yer alan maddelerin amacına hizmet ettiği söylenebilir. Taklit ve çeşitlilik faktörü puanları için elde edilen Cronbach alfa değerinin 0,833 ve McDonald omega değerinin 0,842 olduğu belirlenmiş, bu değerler 0,70 'den yüksek oldu için bu faktörden elde edilen ölçek puanlarının güvenilir olduğu söylenebilir. Ses ve sözcük kullanımı faktöründeki maddeler için düzeltilmiş madde-toplam puan korelasyonu değerinin 0,479 ile 0,615 arasında değiştiği görülmektedir. Bu değerler 0,30’un üzerinde olduğu için bu boyutta yer alan maddelerin amacina hizmet ettiği söylenebilir. Ses ve sözcük kullanımı faktörü puanları için elde edilen Cronbach alfa değerinin 0,746 ve McDonald omega değerinin 0,762 olduğu belirlenmiş, bu değerler 0,70'den yüksek oldu için bu faktörden elde edilen ölçek puanlarının güvenilir olduğu söylenebilir.

\section{NöroPLAY Ebeveyn Oyun Davranış Değerlendirme Ölçeği Ölçeği}

NöroPlay yönteminin izlenmesinde kullanılan NöroPLAY Ebeveyn Oyun Davranış Değerlendirme Ölçeği Ölçeği 33 maddeden oluşmaktadır. Ölçek maddeleri yazılırken ilgili alan taramas1 (Charman et al. 2003; Kasari, 2010; Casenhiser, 2013; Diken \& Mahoney 2013; Ingersol \& Wainer 2013; Kasari, 2014; Liao et al. 2014; Rahman et al. 2016; Ginn, 2017; Green et al. 2017; Shire et al. 2017) ve uzman görüşleri dikkate alınarak hazırlanmıştır. Maddeler otizm spektrumu tanısı olan çocuğa sahip ebeveynlerin çocukları ile oyun davranışlarını değerlendirmeye yönelik olarak yazılmıştır. NöroPLAY Ebeveyn Oyun Davranış Değerlendirme Ölçeği ebeveynin kullandığı sözel ifadeler, yönlendirici olmayan davranışlar, çocuğun liderliğini takip etmesi, çocuğun dikkatini destekleyici yaklaşımları, oyundaki etkileşim becerileri ve oyundaki etkileşim becerileri ile ilgili maddeleri içermektedir.

\section{NöroPLAY Ebeveyn Oyun Davranış Değerlendirme Ölçeği ölçümlerine ait geçerlik}

\section{bulgular1}

NöroPLAY Ebeveyn Oyun Davranış Değerlendirme Ölçeğine yönelik yazılan maddelerin amacına hizmet etme durumunu ve belirttiği yapıyı incelemek amacıyla temel bileşenler analizine dayalı faktör analizi yapılmıştır. Faktör analizi yapılırken faktör yük değerlerinin 0,30 'dan yüksek olmasına ve binişik madde olmamasına dikkat edilmiştir. Faktör yük değeri 0,30'dan düşük olanlar ve binişik olan maddeler analiz dışında bırakılarak analizler tekrarlanmıştır. Bu bağlamda 8 madde (7-12-1317-18-21-24-32) analiz dışında bırakılmıştır. En son gerçekleștirilen faktör analizi için hesaplanan KMO değeri 0,832 ve Bartlett istatistiği değeri 1810,904 (sd =300, p<0,05) olarak belirlenmiştir. 
Buna göre, örneklem büyüklüğünün yeterli ve veri setinin faktörleşmeye uygun olduğu söylenebilir.

Faktör analizi sonucunda elde edilen faktör yük değerleri ve açıklanan varyans oranları Tablo 6'da sunulmuştur.

Tablo 6. NöroPLAY Ebeveyn Oyun Davranış Değerlendirme Ölçeği faktör analizi sonucunda elde edilen özdeğerler ve açılkanan varyans yüzdeleri

\begin{tabular}{|c|c|c|c|}
\hline & Öz Değer & Açıklanan Varyans Oranı & Toplam Açıklanan Varyans \\
\hline 1 & 7,519 & 30,074 & 30,074 \\
\hline 2 & 3,564 & 14,254 & 44,329 \\
\hline 3 & 2,852 & 11,409 & 55,738 \\
\hline 4 & 1,378 & 5,514 & 61,251 \\
\hline 5 & 1,133 & 4,531 & 65,782 \\
\hline 6 &, 860 & 3,441 & \\
\hline 7 &, 772 & 3,088 & \\
\hline 8 & ,758 & 3,031 & \\
\hline 9 & 665 & 2,658 & \\
\hline 10 &, 583 & 2,333 & \\
\hline 11 &, 579 & 2,318 & \\
\hline 12 &, 552 & 2,208 & \\
\hline 13 & ,495 & 1,981 & \\
\hline 14 & 427 & 1,708 & \\
\hline 15 & ,408 & 1,631 & \\
\hline 16 & ,388 & 1,553 & \\
\hline 17 & 332 & 1,329 & \\
\hline 18 & 327 & 1,307 & \\
\hline 19 & 278 & 1,113 & \\
\hline 20 & ,269 & 1,075 & \\
\hline 21 & 232 & ,929 & \\
\hline 22 & 186 &, 742 & \\
\hline 23 & ,173 & 692 & \\
\hline 24 & 146 & ,586 & \\
\hline 25 & ,124 & ,496 & \\
\hline
\end{tabular}

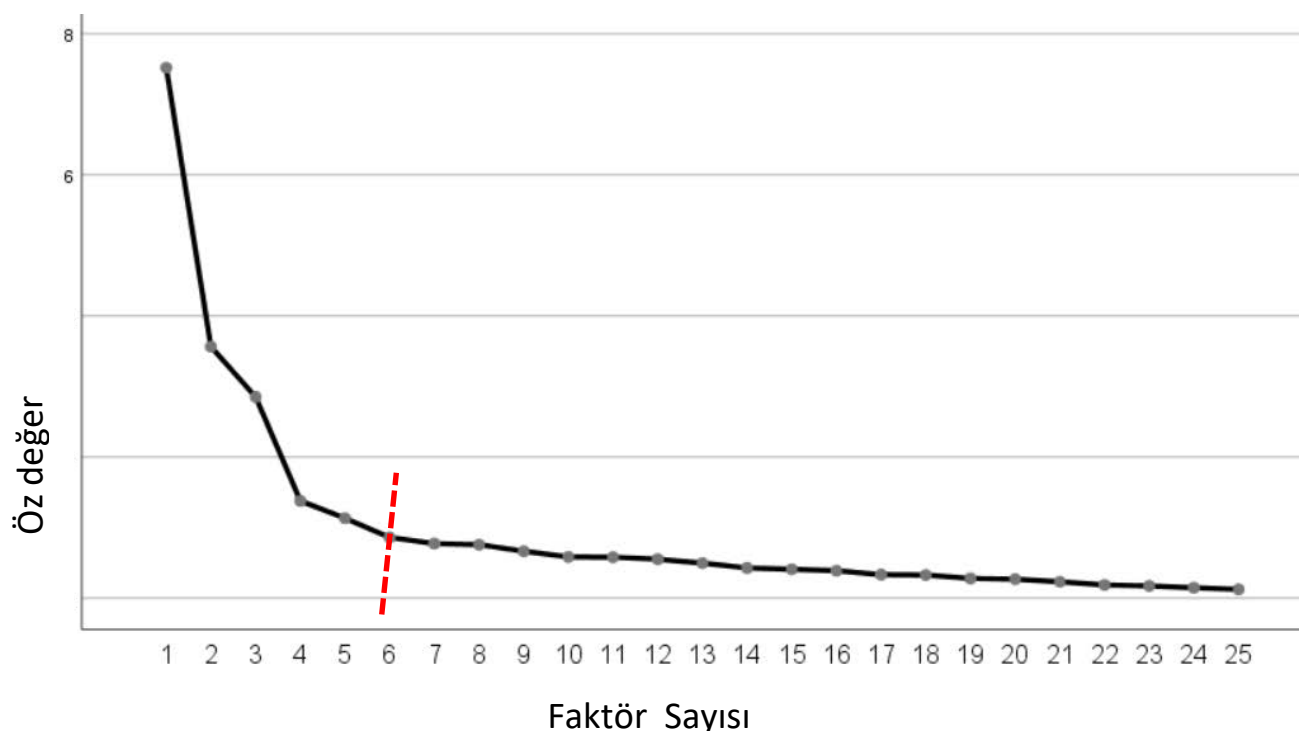

Şekil 3. NöroPLAY Ebeveyn Oyun Davranış Değerlendirme Ölçeği yamaç-birikinti grafiği 
Tablo 6 incelendiğinde öz değeri 1’in üzerinde olan beş faktör olduğu görülmektedir. Buna göre NöroPLAY Ebeveyn Oyun Davranış Değerlendirme Ölçeğinin beş faktörden oluştuğu söylenebilir. Ayrıca Şekil. 3'de verilen yamaç-birikinti grafiği (scree plot) incelendiğinde grafiğin düzleşmeye başladığı kısmın beşinci boyuttan sonra olduğu görülmektedir. Buna göre, yamaç birikinti grafiğinin de beş boyutlu yapıyı desteklediği söylenebilir. NöroPLAY Ebeveyn Oyun Davranış Değerlendirme Ölçeği açıklanan varyans oranı ise \%65,78 olarak tespit edilmiştir. Diğer bir deyişle 25 madde beş boyutlu yapıdaki varyansın \%65,78’ini açıklamaktadır. NöroPLAY Ebeveyn Oyun Davranış Değerlendirme Ölçeğinde kalan maddelerin faktörlere göre dağılımı ve faktör yük değerleri Tablo 7'de sunulmuştur.

Tablo 7. NöroPLAY Ebeveyn Oyun Davranış Değerlendirme Ölçeği faktör yük değerleri

\begin{tabular}{|c|c|c|c|c|c|}
\hline & \multicolumn{5}{|c|}{ Faktör } \\
\hline & 1 & 2 & 3 & 4 & 5 \\
\hline 1. Sevecen, mutlu bir ses tonu ile konuşur. & ,736 & & & & \\
\hline 2. Çocuk ile arka pozisyondan konuşmaya çalışmaz. & 802 & & & & \\
\hline 3. İletişim kurma ve konuşma esnasinda göz teması kurmaya özen gösterir. & ,794 & & & & \\
\hline 5. Çocuğa gülümser. & ,832 & & & & \\
\hline 4. Oyuncakları yüz/ göz hizasında tutarak oynamaya özen gösterir. & & ,747 & & & \\
\hline 6. Oyun sırasında farklı ses tonlamaları yaparak konuşur. & &, 540 & & & \\
\hline 19. Ebeveyn çocuğun çıkardığı anlamsız sesleri anlamlandırır. & & ,802 & & & \\
\hline $\begin{array}{l}\text { 8. Oyun sürecinde çocukla jest ve mimiklerini kullanarak sözel/fiziksel temasta } \\
\text { bulunur. }\end{array}$ & & &, 531 & & \\
\hline $\begin{array}{l}\text { 9. Çocuk ile iletişime geçmek için oynadığı oyuna ve oyun materyali/ oyuncağa } \\
\text { dahil olmaya çalışır. }\end{array}$ & & & ,884 & & \\
\hline 10. Çocuğun oyununa dahil olduğunda iletişimi sürdürmeye çabalar. & & & ,794 & & \\
\hline $\begin{array}{l}\text { 11. Çocuğun hareketlerini, oyun ve oyun materyali/ oyuncağa yönelimini takip } \\
\text { eder. }\end{array}$ & & & ,701 & & \\
\hline 20. Sembolik (miş gibi) oyun kurar. & & & & ,732 & \\
\hline 22. Çocuğun tek başına oynamasına izin vermez. & & & & ,444 & \\
\hline $\begin{array}{l}\text { 25. Uzun ve karmaşık cümle yapılarından uzak durarak kısa ve net ifadeler } \\
\text { kullanır. }\end{array}$ & & & & 848 & \\
\hline 30. Bebek konuşması yapmadan, doğal konuşmasını kullanarak oynar. & & & & 814 & \\
\hline $\begin{array}{l}\text { 31. Çocuğun elini tutup istediği oyun davranışını çocuğa zorla yaptırmaya } \\
\text { çalışmaz. }\end{array}$ & & & & ,838 & \\
\hline 33. Neden-sonuç ifadelerine yer verir. & & & & ,742 & \\
\hline $\begin{array}{l}\text { 14. Çocuğun problemli davranışlarını anlamlı şekilde bölerek uyarılardan } \\
\text { kaçınır. }\end{array}$ & & & & & ,904 \\
\hline 15. Öğretme odaklı oyun örüntüleri sergilemez. & & & & & 843 \\
\hline 16. Çocuğun oyununu genişletir. & & & & & 681 \\
\hline $\begin{array}{l}\text { 23. Çocuğun oyun materyali/oyuncak veya oyun seçimi yapmasi için en az 4-6 } \\
\text { saniye bekler. }\end{array}$ & & & & & 611 \\
\hline 26. Oyun sırasinda oyun materyalli/oyuncakları sirayla sunar. & & & & & ,766 \\
\hline $\begin{array}{l}\text { 27. Oyun için çıkarılmış oyun materyali oyuncak sayısını çocuğun dikkatine göre } \\
\text { azaltarak, oyun akışında ortamdan uzaklaştırır. }\end{array}$ & & & & & 807 \\
\hline $\begin{array}{l}\text { 28. Ebeveyn oyunda nasıl bir oyun kuracağına dair uzunca düşünmeden oyun } \\
\text { akışında doğaçlayıcı hareketlerle oyunu kurup sürdürür. }\end{array}$ & & & & & ,728 \\
\hline $\begin{array}{l}\text { 29. Çocuğun ilgisini çeken oyun materyali/oyuncak yerine başka bir oyun } \\
\text { materyali/oyuncak ile oyun kurmaya çalışmaz. }\end{array}$ & & & & & 687 \\
\hline
\end{tabular}

Tablo 7 incelendiğinde faktör 1 için faktör yük değerleri 0,736 ile 0,832 arasında, faktör 2 için 0,540 ile 0,802 arasında, faktör 3 için 0,531 ile 0,884 arasında, faktör 4 için 0,444 ile 0,848 ve faktör 5 için 
0,611 ile 0,904 arasında değiştiği görülmektedir. Her bir madde için faktör yük değeri 0,30’un yüksek olduğu için maddelerin bulundukları boyutta amacına hizmet ettikleri söylenebilir. Faktörler altında yer alan maddeler incelendiğinde birinci faktör "Oyundaki Etkileşim Becerileri”, ikinci faktör "Sözel İfade Kullanımı”, üçüncü faktör "Dikkati Destekleyici Yaklaşımlar”, dördüncü faktör “Oyundaki İletişim Becerileri” ve beşinci faktör "Yönlendirici Olmayan Yaklaşımlar" olarak isimlendirilmiştir. Faktörler altındaki maddeler incelendiğinde madde 4 (Oyuncakları yüz/ göz hizasında tutarak oynamaya özen gösterir.) oyundaki etkileşim becerilerine daha yakın bir madde olmasına rağmen sözel ifade kullanımında yük vermiştir. Bu durum uzmanlar tarafından sözel ifade kullanımında da bir etkileşim becerisi kullanma gerektiğinden boyutta yer alması uygun görülmüş ve ölçekte kalması gerektiğine karar verilmiştir.

NöroPLAY Ebeveyn Oyun Davranış Değerlendirme Ölçeği 25 maddeden oluşan beş boyutlu bir yapı göstermektedir. Elde edilen bu beş boyutlu yapının doğrulanması amacıyla hedef gruptan altı ay sonra toplanan veriler üzerinden doğrulayıcı faktör analizi yapılmıştır. Doğrulayıcı faktör analizi yapılırken uyum indeksi değerleri, faktör yük değerleri ve hata varyansları incelenerek model veri uyumu değerlendirilmiştir. Uyum indeksi değerleri, faktör yük değerleri (max-min) ve hata varyans1 (max-min) değerleri Tablo 8'de sunulmuştur. Ayrıca analiz sonucunda elde edilen ölçme modeli Şekil 4'de sunulmuştur.

Tablo 8. NöroPLAY Ebeveyn Oyun Davranış Değerlendirme Ölçeği Ölçeği Doğrulayıcı Faktör Analizi Sonuçları

\begin{tabular}{|c|c|c|c|c|c|c|c|c|c|}
\hline & & & & & & & & $\begin{array}{c}\text { Faktör Yük } \\
\text { Değerleri }\end{array}$ & $\begin{array}{c}\text { Hata } \\
\text { Varyanslar1 }\end{array}$ \\
\hline & $\chi^{2}$ & $\chi^{2} / \mathrm{sd}$ & $\mathrm{p}$ & CFI & GFI & NFI & RMSEA & $\max \quad \min$ & $\max \quad \min$ \\
\hline Ölçek & 439,38 & 1,64 & 0,00 & 0,93 & 0,72 & 0,83 & 0,084 & 0,72 & 0,89 \\
\hline Önerilen & & $\chi^{2} / \mathrm{sd} \leq 3$ & & $\geq 90$ & $\geq 90$ & $\geq 90$ & $\leq 0,080$ & $\geq 0,30$ & $\leq 0,90$ \\
\hline
\end{tabular}

Tablo 8 incelendiğinde $\chi 2 / s d$ değerinin 3’ten küçük olduğu görülmektedir ve buna göre modelin veriye çok iyi uyum gösterdiği söylenebilir. CFI değeri 0,93 olarak tespit edilmiştir ve bu değerin 0,90'nın üzerinde olması modelin veriye çok iyi uyum gösterdiği anlamına gelmektedir. Ancak GFI ve NFI değerleri 0,90’nın altında kaldığından model veri uyumunun olmadığını göstermektedir. RMSEA indeksi açısından değerlendirildiğinde ise bu indeksin model için 0,084 olduğu saptanmıştır ve bu değer model veri uyumu kabul değerine olan 0,080'ne çok yakın olduğu söylenebilir. Bu durum model veri uyumunun bu indeks değerine göre sağlanmadığ anlamına gelir. Uyum indeksleri genel olarak değerlendirildiğinde beş boyutlu modelin veriye kısmen uyum sağladığ1 görülmektedir. Ölçekteki tüm maddelerin faktör yük değerleri 0,30'dan yüksektir. Buna göre, tüm maddelerin amacına hizmet ettiği yorumu yapılabilir. 


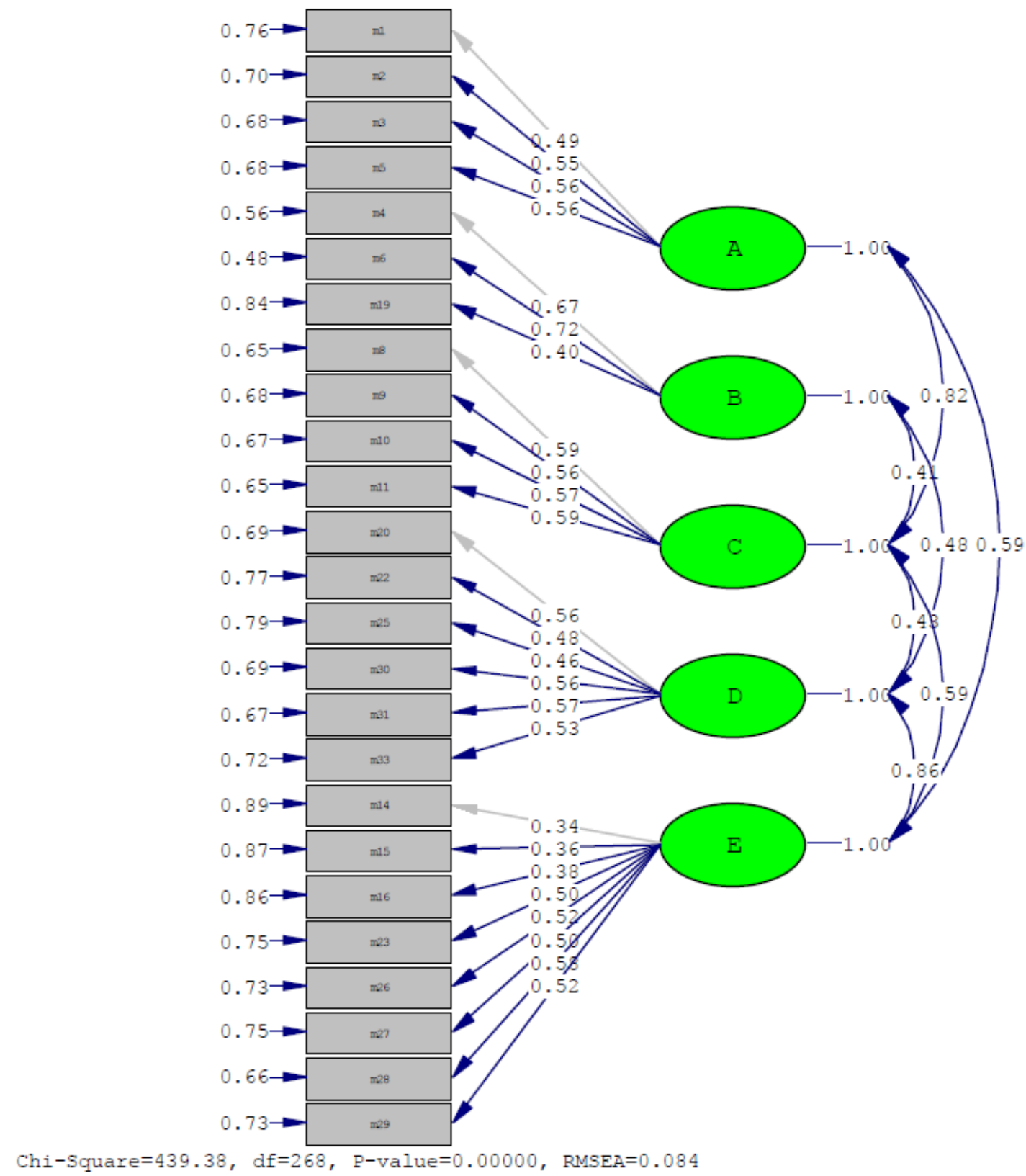

Şekil 4. NöroPLAY Ebeveyn Oyun Davranış Değerlendirme Ölçeği Ölçme Modeli

\section{NöroPLAY Ebeveyn Oyun Davranış Değerlendirme Ölçeği ölçümlerine ait güvenirlik}

\section{bulgular1}

NöroPLAY Ebeveyn Oyun Davranış Değerlendirme Ölçeğinin belirlenen faktörlerinde yer alan maddelerin madde ayırt ediciliğini incelemeye yönelik düzeltilmiş madde-toplam puanı korelasyonu ve faktörlerin güvenirliğinin belirlenmesine ilişkin Cronbach alfa değerleri ile McDonald Omega değerleri Tablo 9'da sunulmuştur. 
Tablo 9. NöroPLAY Ebeveyn Oyun Davranış Değerlendirme Ölçeği düzeltilmiş madde-toplam puanı korelasyonu, Cronbach alfa ile MacDonald Omega değerleri

\begin{tabular}{|c|c|c|c|c|}
\hline & $\begin{array}{l}\text { Madde } \\
\text { No }\end{array}$ & $\begin{array}{c}\text { Düzeltilmiş Madde -Toplam } \\
\text { Korelasyonu }\end{array}$ & Cronbach alfa & $\begin{array}{c}\text { McDonald } \\
\text { Omega }\end{array}$ \\
\hline \multirow{4}{*}{ Oyundaki Etkileşim Becerileri } & 1 & ,698 & \multirow{4}{*}{0,821} & \multirow{4}{*}{0,830} \\
\hline & 2 & ,618 & & \\
\hline & 3 &, 577 & & \\
\hline & 5 & ,743 & & \\
\hline \multirow{3}{*}{ Sözel İfade Kullanımı } & 4 & ,484 & \multirow{3}{*}{0,602} & \multirow{3}{*}{0,638} \\
\hline & 6 & ,441 & & \\
\hline & 19 & ,350 & & \\
\hline \multirow{4}{*}{ Dikkati Destekleyici Yaklaşımlar } & 8 & ,548 & \multirow{4}{*}{0,833} & \multirow{4}{*}{0,841} \\
\hline & 9 & ,799 & & \\
\hline & 10 & ,613 & & \\
\hline & 11 & ,703 & & \\
\hline \multirow{6}{*}{ Oyundaki İletişim Becerileri } & 20 & ,565 & \multirow{6}{*}{0,844} & \multirow{6}{*}{0,856} \\
\hline & 22 &, 502 & & \\
\hline & 25 & ,714 & & \\
\hline & 30 & ,656 & & \\
\hline & 31 &, 756 & & \\
\hline & 33 & 643 & & \\
\hline \multirow{8}{*}{ Direktif Olmayan Yaklaşımlar } & 14 & ,747 & \multirow{8}{*}{0,888} & \multirow{8}{*}{0,901} \\
\hline & 15 & ,657 & & \\
\hline & 16 & ,617 & & \\
\hline & 23 & ,491 & & \\
\hline & 26 &, 740 & & \\
\hline & 27 &, 752 & & \\
\hline & 28 & ,755 & & \\
\hline & 29 & 666 & & \\
\hline
\end{tabular}

Tablo 9 incelendiğinde oyundaki etkileşim faktöründeki maddeler için düzeltilmiş madde-toplam puan korelasyonu değerinin 0,577 ile 0,743 arasında değiştiği görülmektedir. Bu değerler 0,30’un üzerinde olduğu için bu boyutta yer alan maddelerin amacına hizmet ettiği söylenebilir. Oyundaki etkileşim becerileri faktörü puanları için elde edilen Cronbach alfa değerinin 0,821 ve McDonald omega değerinin 0,830 olduğu belirlenmiş, bu değerler 0,70 'den yüksek oldu için bu faktörden elde edilen ölçek puanlarının güvenilir olduğu söylenebilir. Sözel ifade kullanımı faktörü için düzeltilmiş madde-toplam puan korelasyonu değerinin 0,350 ile 0,484 arasında değiştiği görülmektedir. Bu değerler 0,30'un üzerinde olduğu için bu boyutta yer alan maddelerin amacina hizmet ettiği söylenebilir. Tekrarlı ve devam eden davranışlar faktörü puanları için elde edilen Cronbach alfa değerinin 0,602 ve McDonald omega değerinin 0,638 olduğu belirlenmiş, Salvucci, Walter, Conley, Fink, \& Saba, (1997) tarafindan 0,50 ile 0,80 arasındaki güvenirlik katsayılarının orta düzeyde güvenilir kabul edilebileceği sonucu dikkate alındığında bu faktörden elde edilen puanların orta düzeyde güvenilir olduğu söylenebilir. Dikkati destekleyici yaklaşımlar faktörü maddeleri için düzeltilmiş madde-toplam puan korelasyonu değerinin 0,548 ile 0,799 arasında değiştiği görülmektedir. Bu değerler 0,30’un üzerinde olduğu için bu boyutta yer alan maddelerin amacina 
hizmet ettiği söylenebilir. Dikkati destekleyici yaklaşımlar faktörü puanları için elde edilen Cronbach alfa değerinin 0,833 ve McDonald omega değerinin 0,841 olduğu belirlenmiş, bu değerler 0,70'den yüksek oldu için bu faktörden elde edilen ölçek puanlarının güvenilir olduğu söylenebilir. Oyundaki iletişim becerileri faktörü maddeleri için düzeltilmiş madde-toplam puan korelasyonu değerinin 0,502 ile 0,756 arasında değiştiği görülmektedir. Bu değerler 0,30’un üzerinde olduğu için bu boyutta yer alan maddelerin amacına hizmet ettiği söylenebilir. Oyun katılım davranışları faktörü puanları için elde edilen Cronbach alfa değerinin 0,844 ve McDonald omega değerinin 0,856 olduğu belirlenmiş, bu değerler 0,70'den yüksek oldu için bu faktörden elde edilen ölçek puanlarının güvenilir olduğu söylenebilir. Yönlendirici olmayan yaklaşımlar faktörü maddeleri için düzeltilmiş madde-toplam puan korelasyonu değerinin 0,491 ile 0,755 arasında değiştiği görülmektedir. $\mathrm{Bu}$ değerler 0,30’un üzerinde olduğu için bu boyutta yer alan maddelerin amacina hizmet ettiği söylenebilir. Yönlendirici olmayan yaklaşımlar faktörü puanları için elde edilen Cronbach alfa değerinin 0,888 ve McDonald omega değerinin 0,901 olduğu belirlenmiş, bu değerler 0,70'den yüksek oldu için bu faktörden elde edilen ölçek puanlarının güvenilir olduğu söylenebilir.

\section{SONUÇ ve TARTIŞMA}

NöroPLAY yönteminde kullanılan geçerlik ve güvenirlik düzeyi yüksek iki ölçme aracının geliştirilmesini amaçlayan bu çalışmada ölçme araçlarına ait yapı ortaya konulmuştur. Ölçme araçlarından biri; çocuğun oyuna pasif katılımı, aktif oyun davranışı, oyun içindeki duyusal problemleri gösteren davranışlar, oyuncakları amacına uygun kullanmaması, oyuncakları tekrarlı şekilde kullanması, tekrarlı oyun davranışları, oyundaki dikkat süreleri, taklit ve çocuğun oyundaki ses/sözcük kullanımı ile ilgili maddeleri içeren NöroPLAY Oyun Davranış Değerlendirme Ölçeğidir. Açımlayıcı faktör analizi sonucunda elde edilen NöroPLAY Oyun Davranış Değerlendirme Ölçeğinin 22 madde ve dört boyutlu yapıda olduğu belirlenmiştir. Belirlenen dört boyutlu yapıda Faktörler altında yer alan maddeler incelenerek birinci faktör "Oyun Katıllım Davranışları", ikinci faktör “Tekrarlı ve Devam Eden Davranışlar”, üçüncü faktör "Taklit ve Çeşitlilik” ve dördüncü faktör “Ses ve Sözcük Kullanımı” olarak isimlendirilmiştir. Birinci faktörün açıkladığ1 varyans \%38,64; ikinci faktörün açıkladığ1 varyansın \%14,27; üçüncü faktörün açıkladığ1 varyans $\% 7,33$ ve dördüncü faktörün açıkladığı varyans \%5,62 olduğu belirlenmiştir. NöroPLAY Oyun Davranış Değerlendirme Ölçeğinin dört boyutlu yapısının açıkladı̆̆ı toplam varyansın \%68,86's1 olduğu belirlenmiştir. Açıklanan varyans değerinin yüksek olması, ilgili kavram ya da yapının o denli iyi ölçüldüğünün bir göstergesidir. Analize dahil edilen değişkenlerle ilgili toplam varyansın 2/3'ünü(yaklaşık \%67'si) açıkladığı miktar önemli görülmektedir (Büyükzötürk, 2011). 
NöroPLAY Oyun Değerlendirme Ölçeği için elde edilen açıklanan toplam varyansın \%68,86 olması bu konuda ölçek için uygun boyut sayısına karar verildiğinin göstergesidir. Aynıca Kline (1994) madde faktör yük değerlerinin 0,60 ve üstünde olmasını yüksek,0,30-.59 olmasını orta düzeyde iyi bir ölçüt olduğu anlamına gelmektedir. Çalışma kapsamında NöroPLAY Oyun Değerlendirme Ölçeği için birinci faktöre ait faktör yük değerlerinin 0,649 ile 0,923 arasında, ikinci faktöre ait faktör yük değerlerinin 0,539 ile 0,847 arasında, üçüncü faktöre ait faktör yük değerlinin 0,641 ile 0,821 arasında ve dördüncü faktöre ait faktör yük değerlerinin 0,594 ile 0,808 arasında değiştiği görülmektedir. Boyutlar altında yer alan her bir madde için faktör yük değeri 0,30’un yüksek olduğu için maddelerin bulundukları boyutta amacına hizmet ettikleri söylenebilir.

Çalışma kapsamında geliştirilen bir diğer ölçek ise, Ebeveyn Oyun Davranışı Değerlendirme Ölçeğidir. Maddeler OSB tanısı olan çocuğa sahip ebeveynlerin çocukları ile oyun davranışlarını değerlendirmeye yönelik olarak yazılmıştır ve madde içerikleri ebeveynin kullandığı sözel ifadeler, direktif olmayan davranışları, çocuğun liderliğini takip etmesi, çocuğun dikkatini destekleyici yaklaşımlanı, oyundaki etkileşim becerileri ve oyundaki etkileşim becerileri ile ilgilidir. Açımlayıcı faktör analizi sonucunda elde edilen Ebeveyn Oyun Davranışı Değerlendirme -Ölçeğinin 25 madde ve beş boyutlu yapıda olduğu belirlenmiştir. Belirlenen dört boyutlu yapıda Faktörler altında yer alan maddeler incelenerek birinci faktör "Oyundaki Etkileşim Becerileri”, ikinci faktör "Sözel İfade Kullanımı”, üçüncü faktör “Dikkati Destekleyici Yaklaşımlar”, dördüncü faktör “'Oyundaki İletişim Becerileri” ve beşinci faktör "Direktif Olmayan Yaklaşımlar" olarak isimlendirilmiştir. Birinci faktörün açıkladığ1 varyans \%30,07; ikinci faktörün açıkladığ1 varyansın \%14,25; üçüncü faktörün açıkladığ1 varyans \%11,41, dördüncü faktörün açıkladığ1 varyans \%5,51 ve beşinci faktörün açıkladığı varyansın \%4,53 olduğu belirlenmiştir. NöroPLAY Ebeveyn Oyun Davranış Değerlendirme Ölçeğinin beş boyutlu yapısının açıladı̆̆ı toplam varyansın \%65,78'dir. NöroPLAY Ebeveyn Oyun Davranış Değerlendirme Ölçeği için elde edilen açılanan toplam varyansın \%65,78 olması bu konuda ölçek için uygun boyut sayısına karar verildiğinin göstergesidir. Çalışma kapsamında NöroPLAY Ebeveyn Oyun Davranış Değerlendirme Ölçeği için birinci faktöre ait faktör yük değerlerinin 0,736 ile 0,832 arasında, ikinci faktöre ait faktör yük değerlerinin 0,540 ile 0,802 arasında, üçüncü faktöre ait faktör yük değerlinin 0,531 ile 0,884 arasında, dördüncü faktöre ait faktör yük değerlerinin 0,444 ile 0,848 arasında ve beşinci faktör için faktör yük değerlerinin 0,611 ile 0,904 arasında değiştiği görülmektedir. Boyutlar altında yer alan her bir madde için faktör yük değeri 0,30'un yüksek olduğu için maddelerin bulundukları boyutta amacina hizmet ettikleri söylenebilir. 


\section{Sonuç ve Öneriler}

NöroPLAY yönteminde kullanılan NöroPLAY Oyun Davranış Değerlendirme Ölçeği ve Ebeveyn Oyun Davranış Değerlendirme Ölçeğinden elde edilen ölçümlerin geçerli ve güvenilir olduğu ortaya konulmuştur. NöroPLAY Ebeveyn Oyun Davranış Değerlendirme Ölçeği için boyutlara ait hesaplanan Cronbach alfa değerlerinin 0,602 ile 0,888 arasında ve McDonald Omega değerlerinin 0,638 ile 0,901 arasında değiştiği belirlenmiştir. NöroPLAY Oyun Davranış Değerlendirme Ölçeği boyutlara ait hesaplanan Cronbach alfa değerlerinin 0,746 ile 0,938 arasinda ve McDonald Omega değerlerinin 0,762 ile 0,938 arasında değiştiği belirlenmiştir. Çalışmanın sonucunda alandaki uygulayıcılara, araştırmacılara şu önerilerde bulunulabilir:

- Ölçeğin daha geniş Türkiye örneklemi için norm çalışması planlanabilir.

- NöroPLAY yönteminin kullanıldığı deneysel ve boylamsal çalışmalarda ölçme araçlarının kullanımı arttırlabilir.

- $\mathrm{Bu}$ alanda çalısacak araştırmacılara fraklı yöntemler ve araçların oluşturulması için yol gösterici olabilir.

\section{KAYNAKÇA}

Aksoy, A.B. \& Dere Çiftçi H. (2014). Erken çocukluk döneminde oyun. Ankara: Pegem Yayıncllık.

Aldred, C., Taylor, C., Wan, M. W., \& Green, J. (2018). Using video feedback strategies in parentmediated early autism intervention. In Handbook of Parent-Implemented Interventions for Very Young Children with Autism (pp. 221-239). Springer, Cham.

American Psychiatric Association. (2013). Diagnostic and statistical manual of mental disorders (DSM$5 \circledR)$. American Psychiatric Pub.

Bradshaw, J., Koegel, L. K., \& Koegel, R. L. (2017). Improving functional language and social motivation with a parent-mediated intervention for toddlers with autism spectrum disorder. Journal of Autism and Developmental Disorders, 47(8), 2443-2458. DOI: 10.1007/s10803-017$3155-8$

Bussanich, P., Hartley, S. L., \& Bolt, D. (2017). Parental attributions for positive behaviours in children with autism spectrum disorder. Journal of Intellectual Disability Research, 61(7), 643655. https://doi.org/10.1111/jir.12373

Büyüköztürk, Ş. (2011). Sosyal bilimler için veri analið̨ el kitabı. (13. Baskı). Ankara: Pegem Akademi

Büyüköztürk, Ş. Kılıç Çakmak, E., Akgün, Ö. E., Karadeniz, Ş., \&Demirel, F. (2012). Bilimsel araştırma yöntemleri. Ankara: Pegem Akademi. 
Case-Smith J, Kuhaneck HM, (2008). Play preferences of typically developing children and children with developmental delays between ages 3 and 7 years. OTJR: Occupation, Participation and Health, 28(1), 19-29. https:// doi.org/10.3928/15394492-20080101-01

Charman, T., Baron-Cohen, S., Swettenham, J., Baird, G., Drew, A., \& Cox, A. (2003). Predicting language outcome in infants with autism and pervasive developmental disorder. International Journal of Language \& Communication Disorders, 38(3), 265-285. DOI: $10.1080 / 136820310000104830$

Crocker. L., \& Algina. J. (1986). Introduction to classical and modern test theory. Philadelphia: Harcourt Brace Jovanovich College Publishers.

Çokluk. Ö., Şekercioğlu. G., \& Büyüköztürk. Ş. (2010). Sosyal bilimler için çok değişsenli istatistik SPSS ve LISREL uygulamalar. (1. Baskı). Ankara: Pegem Akademi.

Dammann, C., Althoff, C., Hope, S., \& Ausderau, K. (2017). Parent-mediated interventions with children with autism spectrum disorder: A systematic review. American Journal of Occupational Therapy, 71(4_Supplement_1), 7111515226p1. DOI: 10.5014/ajot.2019.030015

Ekici, B. \& Bıçakçı, M.Y. (2017). Nöroplay yöntemi. 2.Baskı. Ankara: Ekinoks Yayınevi.

Ekici, B., Bıçakçı, M.Y., Gürkan, E.N., Unay, Ö.S. \& Tatlı, B. (2019). Otizmde Ebeveyn Aracılı Yoğun Müdahale Yöntemi Nöroplay. Journal of the Child/Cocuk Dergisi, 19(3), 158-162.

Ekici, B., Bıçakçı, M. Y., Dursun, S. Ş., Kutlu, F., \& Gürkan, E. N. (2018). Investıgatıon of the effect of neuroplay method on developmental processes of children with autism spectrum disorders and parental interactions. People: International Journal of Social Sciences, 4(3). 18301849. do1: https://doi.org/10.20319/pijss.2019.43.18301849

Ekici, B., Konuk, F. K., Dursun, S.. S., Unay, Ö. S., \& Tatlı, B. (2020). Neuroplay method combined with home-based Ayres sensory integration for autism: A case report. Journal of Surgery and Medicine, 4(3), 246-247.

Emmons, P. \& Anderson, L, (2005). Understanding sensory dysfunction: learning, development and sensory dysfunction in autism spectrum disorders, ADHD, learning disabilities and bipolar disorder. Jessica Kingsley Publishers.

Flippin, M., \& Watson, L. R. (2018). Parental broad autism phenotype and the language skills of children with autism spectrum disorder. Journal of autism and developmental disorders, 48(6), 1895-1907. doi: 10.1007/s10803-017-3431-7

Frost, K. M., Russell, K. and Ingersoll, B. (2021). Using qualitative content analysis to understand the active ingredients of a parent-mediated naturalistic developmental behavioral intervention. Autism, https://doi.org/10.1177/13623613211003747

Gassaloğlu, S. İ., Baykara, B., Avcil, S., \& Demiral, Y. (2016). Çocukluk Otizmi Derecelendirme Ölçeği Türkçe Formunun Geçerlik ve Güvenilirlik Çalışması. Türk Psikijyatri Dergisi, 27(4), 266-274. 
Ginn, N. C., Clionsky, L. N., Eyberg, S. M., Warner-Metzger, C., \& Abner, J. P. (2017). Childdirected interaction training for young children with autism spectrum disorders: Parent and child outcomes. Journal of Clinical Child \& Adolescent Psychology, 46(1), 101-109. DOI: 10.1080/15374416.2015.1015135

Green, J. Pickles, A. Pasco, G., Bedford, R., Wan, M.W., Elsabbagh, M. \& Charman, T, (2017). Randomisedtrial of a parent-mediated intervention for infants at high risk for autism: longitudinal outcomes to age 3 years. Journal of Child Psychology and Psychiatry, 58(12), 13301340. DOİ: $10.1111 /$ jcpp. 12728

Green, J., Charman, T., McConachie, H., Aldred, C., Slonims, V., Howlin, P., ... \& Barrett, B. (2010). Parent-mediated communication-focused treatment in children with autism (PACT): a randomised controlled trial. The Lancet, 375(9732), 2152-2160. DOİ: 10.1016/S0140-6736(10)60587-9

Hamm, E.M., Mistrett, S.G. \& Ruffino, A.G. (2005). Play outcomes and satisfaction with toys and technology of young children with special needs. Journal of Special EducationTechnology, 21(1), 29-35. https://doi.org/10.1177/016264340602100103

Ingersoll, B.R., Wainer, A.L, (2013). Pilot study of a school-based parent training program for

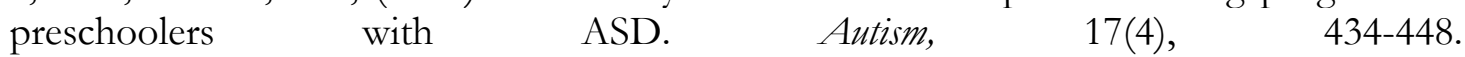
https://doi.org/10.1177/1362361311427155

Kasari C, Sigman M, Mundy P, Yirmiya N, (1988). Caregiver interactions with autistic children. Journal of Anormal Child Psychology, 16(1), 45-56. https://doi.org/10.1007/BF00910499

Kasari, C., Gulsrud, A.C., Wong, C., Kwon, S. \& Locke, J. (2010). Randomized controlled caregiver mediated join tengagement intervention for toddlers with autism. Journal of Autism And Developmental Disorders, 40(9), 1045-1056. DOİ: 10.1007/s10803-010-0955-5

Kasari, C., Lawton, K., Shih, W., Barker, T.V., Landa, R., Lord, C. \& Şentürk, D. (2014). Caregivermediated intervention for low-resourced preschoolers with autism: An RCT. Pediatrics, 134(1), e72-e79. DOI: 10.1542/peds.2013-3229

Kasari, C., Gulsrud, A., Paparella, T., Hellemann, G. \& Berry, K. (2015). Randomized comparative efficacy study of parent-mediated interventions for toddlers with autism. Journal of Consulting And Clinical Psychology, 83(3), 554. DOİ: 10.1037/a0039080

Kline. P. (1994). An easy guide to factor analysis. New York: Routledge.

Liao, S. T., Hwang, Y. S., Chen, Y. J., Lee, P., Chen, S. J., \& Lin, L. Y. (2014). Home-based DIR/Floortime ${ }^{\mathrm{TM}}$ intervention program for preschool children with autism spectrum disorders: Preliminary findings. Physical \& Occupational Therapy In Pediatrics, 34(4), 356-367. DOI: $10.3109 / 01942638.2014 .918074$

Parsons, D., Cordier, R., Vaz, S., \& Lee, H. C. (2017). Parent-mediated intervention training delivered remotely for children with autism spectrum disorder living outside of urban areas: Systematic review. Journal of Medical Internet Research, 19(8), e198. DOI: 10.2196/jmir.6651

Pickles, A., Le Couteur, A., Leadbitter, K., Salomone, E., Cole-Fletcher, R., Tobin, H., ... \& Aldred, C. (2016). Parent-mediated social communication therapy for young children with autism 
(PACT): long-term follow-up of a randomised controlled trial. The Lancet, 388(10059), 2501-2509. DOI: 10.1016/S0140-6736(16)31229-6

Rahman, A., Divan, G., Hamdani, S.U., Vajaratkar, V., Taylor, C., Leadbitter, K. \& Patel, V. (2016). Effectiveness of the parent-mediated intervention for children with autism spectrum disorder in South Asia in India and Pakistan (PASS): a randomised controlledtrial. The Lancet Psychiatry, 3(2), 128-136. doi: 10.1016/S2215-0366(15)00388-0.

Salvucci, S., Walter, E., Conley, V., Fink, S., \& Saba, M. (1997). Measurement error studies at the National Center for Education Statistics (NCES). Washington D. C.: U. S. Department of Education.

Schermelleh-Engel, K., Moosbrugger, H., \& Müller, H. (2003). Evaluating the fit of structural equation models: Tests of significance and descriptive goodness-of-fit measures. Methods of Psychological Research Online, 8(2), 23-74.

Schertz, H.H., Odom, S.L., Baggett, K.M. \& Sideris, J.H. (2013). Effects of join tattention mediated learning for toddlers with autism spectrum disorders: An initial randomized controlled study. Early Childhood Research Quarterly, 28(2), 249-258. 10.1016/j.ecresq.2012.06.006

Schopler, E., Reichler, R. J., DeVellis, R. F., \& Daly, K. (1980). Toward objective classification of childhood autism: Childhood Autism Rating Scale (CARS). Journal of Autism And Developmental Disorders, 10(1):91-103. DOI: 10.1007/BF02408436

Schultz, T. R., Schmidt, C. T., \& Stichter, J. P. (2011). A review of parent education programs for parents of children with autism spectrum disorders. Focus On Autism And Other Developmental Disabilities, 26(2), 96-104. https://doi.org/10.1177/1088357610397346

Shire, S.Y., Chang, Y.C., Shih, W., Bracaglia, S., Kodjoe, M. \& Kasari, C, (2017). Hybrid implementation model of community-partnered early intervention for toddlers with autism: A randomizedtrial. Journal of Child Psychology and Psychiatry, 58(5), 612-622. DOI: $10.1111 /$ jcpp. 12672

Siller, M., Hutman, T., \& Sigman, M. (2013). A parent-mediated intervention to increase responsive parental behaviors and child communication in children with ASD: A randomized clinical trial. Journal of Autism and Developmental Disorders, 43(3), 540-555. doi: 10.1007/s10803-012$1584-\mathrm{y}$

Stadnick, N. A., Stahmer, A., \& Brookman-Frazee, L. (2015). Preliminary effectiveness of Project ImPACT: A parent-mediated intervention for children with autism spectrum disorder delivered in a community program. Journal of autism and developmental disorders, 45(7), 20922104. DOI: $10.1007 / \mathrm{s} 10803-015-2376-y$

Tabachnick. B. \& Fidell. L. (2007). Using multivariate statistics. Boston: Allyn and Bacon.

Tonge, B. J., Bull, K., Brereton, A., \& Wilson, R. (2014). A review of evidence-based early intervention for behavioural problems in children with autism spectrum disorder: the core components of effective programs, child-focused interventions and comprehensive treatment models. Current Opinion in Psychiatry, 27(2), 158-165. doi: 10.1097/YCO.0000000000000043. 
Yamaner F, (2001). Beden eğitimi ve sporda temel ilkeler. Bursa:Ekin Kitabevi. 